\title{
Influence of starter culture on the physicochemical properties of rice bran sourdough and physical quality of sourdough bread
}

\author{
Hanis-Syazwani, M., Bolarinwa, I.F., Lasekan, O. and *Kharidah Muhammad \\ Faculty of Food Science and Technology, Universiti Putra Malaysia, 43400 UPM, Serdang, Selangor, \\ Malaysia
}

\author{
Article history: \\ Received: 20 February 2018 \\ Received in revised form: 27 \\ March 2018 \\ Accepted: 30 March 2018 \\ Available Online: 3 April \\ 2018
}

\section{Keywords:}

Rice bran,

Sourdough bread,

Physicochemical properties,

Crumb firmness,

Sensory analysis

\section{DOI:}

https://doi.org/10.26656/fr.2017.2(4).045

\begin{abstract}
The effect of mixed strain culture of lactic acid bacteria (LAB) and Yeast, and yeast or $L$. brevis, L. plantarum, or L. sanfranciscencis on the physicochemical properties $(\mathrm{pH}$, TTA, organic acid, ethanol, and sugar content) of rice bran sourdough was investigated. Starter culture with optimum physicochemical properties was used to ferment rice and wheat bran for sourdough production. Rice and wheat bran sourdough and non-fermented rice and wheat bran were mixed with wheat flour at $10 \%$ substitution level for bread production. Results showed that rice bran fermented with L. plantarum had the best physicochemical properties compared to rice bran sourdough produced by other LAB or mixed culture. The specific volume of bread sample made with rice bran sourdough $\left(4.65 \mathrm{~cm}^{3} / \mathrm{g}\right)$ was higher than that of the bread samples made from wheat bran sourdough $\left(4.32 \mathrm{~cm}^{3} / \mathrm{g}\right)$ and nonfermented bran $\left(3.74-4.24 \mathrm{~cm}^{3} / \mathrm{g}\right)$, but not significantly different from the control $(100 \%$ wheat) bread $\left(4.85 \mathrm{~cm}^{3} / \mathrm{g}\right)$. The crumb colour of the rice bran and rice bran sourdough substituted bread was lighter than that of the other bread samples. Crust colour of all the bread samples was not significantly different $(\mathrm{p}>0.05)$. At the end of 6 days storage period, bread samples from control and wheat bran sourdough were firmer than that from rice bran sourdough, however, crumb firmness values were highest in non-fermented bran substituted bread. Sensory analysis result revealed that rice bran sourdough bread was more acceptable than wheat bran sourdough bread, and non-fermented rice and wheat bran substituted bread.
\end{abstract}

\section{Introduction}

Rice bran is the by-product obtained during rice polishing or milling (Zhang et al., 2012). It comprises of bran and germ, and in some cases may contain some amount of starchy endosperm. Rice bran contains moderate amount of carbohydrate (31-52\%), fiber (27\%) and protein (11.8-15.6\%) (Chinma et al., 2015). Although, the use of wheat bran is gaining increasing popularity in baked goods, there is limited usage of other cereals bran in food industries. For example, rice bran is not commercially utilized for food formulation despite its composition. It is only used in animal feed formulation.

The use of bran in bread making has been reported to weaken the structure and baking quality of dough, decrease bread volume and elasticity of the crumb and thus, reduce the overall quality of bread (Noort et al., 2010). In order to improve the quality of baked goods substituted with bran, many studies have tried to improve the quality of cereal bran by treating it with enzyme (Katina et al., 2006; Sanz Penella et al., 2008), subjecting bran to extrusion process (Gómez et al., 2011), and through particle size reduction and fermentation (Coda et al., 2014).

Generally, fermented cereal bran is not commonly used in food formulation. However, researchers have studied and reported the nutritional importance of fermented cereal bran and sourdough fermentation, and their potentials in improving the quality of bran substituted baked foods (Salmenkallio-Marttila et al., 2001; Poutanen et al., 2009; Katina et al., 2012). Lactic acid bacteria (LAB) and yeasts have been successfully used for bran fermentation (Coda et al., 2015). Rice bran fermented with yeast has been reported to contain significantly higher protein content compared to nonfermented rice bran (Chinma et al., 2014).

Sourdough fermentation is one of the most recently used food biotechnology for improving sensory, 
structural, nutritional properties and shelf life of bread (Gobbetti et al., 2014). During sourdough fermentation, acidification, proteolysis and enzymes activation occurs. These processes lead to biochemical changes which positively affect dough and baked good matrix and thus, enhance the nutritional and functional quality of baked goods (Poutanen et al., 2009; Gobbetti et al., 2014). The evaluation of sourdough fermentation is generally based on parameters such as $\mathrm{pH}$, acidity, and microflora, while the quality of bread prepared with sourdough are determined by low $\mathrm{pH}$ and a high ratio of lactic/acetic acids, high loaf volumes and low rates of staling during storage (Gül et al., 2005). Sourdough fermented by Lactobacillus plantarum has been reported to improve the quality of gluten-free bread (Moore et al., 2008).

The use of rice bran sourdough in taftoon bread (Torkamani et al., 2015) and Iranian bread (Farahmand et al., 2015) has been reported. The aim of this study was to investigate the effect of using Malaysian rice bran sourdough as starter culture in pan bread, and the objectives were to determine the physicochemical properties of rice bran sourdough produced from rice bran fermented with mixed culture of $\mathrm{LAB}$ and yeast, and yeast or $\mathrm{LAB}$, and to determine the sensory attributes and storage stability of rice bran sourdough bread. This study will provide additional information on the use of rice bran sourdough as a functional food ingredient, increase food usage of rice bran and add variety to sourdough bread.

\section{Materials and methods}

\subsection{Materials}

Rice bran (MR 219 variety) was obtained from Padiberas Nasional Berhad rice mill in Sekinchan, Selangor, Malaysia. Commercial baker's yeast (Mauripan $\left.{ }^{\circledR}\right)$ was from AB Mauri Malaysia, SDN, BHD, Selangor Dahrul Elsan. Commercial wheat flour and wheat bran, sugar, salt, and shortening were purchased from a local supermarket in Serdang, Selangor, Malaysia. Rice and wheat bran were sieved using a Haver EML digital plus test sieve shaker (Harver and Boecker, 59302, OELDE, Germany) to particle size of $<$ $300 \mu \mathrm{m}$. Lactic acid bacteria (L. brevis ATCC ${ }^{\circledR}$ 8287 $28 \mathrm{TM}$, L. plantarum ATCC ${ }^{\circledR} 8014^{\mathrm{TM}}$ and $L$. sanfranciscencis ATCC $\left(43332^{\mathrm{TM}}\right.$ ) were purchased from American Type Culture Collection (ATCC). $3 \mathrm{M}^{\mathrm{TM}}$ Petrifilm $^{\mathrm{TM}}$ yeast and mold count plates was purchased from 3M Company, St. Paul, Minnesota, USA. All chemicals and reagents were of analytical grade.

\subsection{Methods}

\subsubsection{Chemical analyses of bran}

Standard AOAC (1995) methods were used for moisture (925.08) and ash (923.03). Crude fibre content was determined using AACC (2000) method 32-10.01. Protein was determined using an automated Protein Analyzer system (Kjeltec ${ }^{\mathrm{TM}} 4400$ Analyser Unit, Sweden) according to the AOAC (1995) Kjedhal method (992.23). Total fat was determined with FOSS Soxtec Automated System 2050 (FOSS, Sweden) according to AOAC method 945.16 (AOAC, 1995). Carbohydrate content was calculated by difference.

\subsubsection{Microbial strains and growth conditions}

The LAB media were prepared according to manufacturer's instruction and sterilized by autoclaving at $121^{\circ} \mathrm{C}$ for $15 \mathrm{~min}$. Lactobacillus brevis (L. brevis) was cultured at $30^{\circ} \mathrm{C}$ on de Man, Rogosa and Sharpe (MRS) agars for $48 \mathrm{~h}$ in aerobic condition, and isolated colonies were transferred into MRS broth incubated at $30^{\circ} \mathrm{C}$ for $48 \mathrm{~h}$ in shaking flask agitated at $100 \mathrm{rpm}$. L. plantarum and $L$. sanfranciscencis were cultured at $37^{\circ} \mathrm{C}$ for $48 \mathrm{~h}$ at atmosphere of $5 \% \mathrm{CO}_{2}$. Cultured MRS broth $(1 \mathrm{ml})$ was mixed with $9 \mathrm{ml}$ of sterile peptone water $0.1 \%(\mathrm{v} / \mathrm{v})$ by vortexing and diluted in ten-folds using serial dilution $\left(10^{-2}\right.$ to $\left.10^{-10}\right)$. Serial suspension $(0.1 \mathrm{ml})$ was incubated on Plate Count Agar and the colonies were counted. The bacteria suspension $\left(10^{9} \mathrm{CFU} / \mathrm{ml}\right)$ in peptone water $(0.1 \%)$ was used for bran fermentation. Yeast colony forming unit (CFU) was determined by the method described by Sullivan and Bradford (2011). Yeast (1 g) was diluted in $100 \mathrm{~mL}$ of $0.31 \mathrm{mM}$ phosphate buffer $(\mathrm{pH}$ 7.2) and homogenized for 5 min using a magnetic stirrer. The solution was serially diluted (1:10), inoculated onto Petrifilm plates and the plates were incubated at $25^{\circ} \mathrm{C}$ for 5 days before the colonies were counted.

\subsubsection{Preparation of rice bran and wheat bran} sourdough

Rice bran sourdough was prepared according to Katina et al. (2006) with some modifications. Rice bran $(100 \mathrm{~g})$ was mixed with distilled water $(130 \mathrm{~g})$, bakers' yeast $(1.25 \mathrm{~g})$ and lactic acid bacteria $(15 \mathrm{ml})$ suspension $\left(10^{9} \mathrm{CFU} / \mathrm{ml}\right)$ in a beaker and covered with aluminum foil. The bran was allowed to ferment at $35^{\circ} \mathrm{C}$ for $16 \mathrm{~h}$ in a fermenting box (Model Fx-11, Good and Well, SDN BHD, Malaysia) to produce sourdough. Seven formulations of rice bran sourdough fermented with mixed culture of LAB $\left(10^{9} \mathrm{CFU} / \mathrm{ml}\right)$ and yeast $\left(10^{7}\right.$ $\mathrm{CFU} / \mathrm{ml})$, L. brevis, L. plantarum, L. sanfranciscencis and yeast (control) were prepared as shown in Table 1, and evaluated for $\mathrm{pH}$, Titratable acidity (TTA), organic acids, ethanol and sugar contents. The starter culture that produced sourdough with optimum parameters was subsequently used to ferment rice and wheat bran for bran sourdough production (as described above). 
Table 1. Rice bran sourdough prepared using yeast ( $\left.10^{7} \mathrm{CFU}\right)$ and/or lactic acid bacteria ( $\left.10^{9} \mathrm{CFU}\right)$

\begin{tabular}{lcc}
\hline $\begin{array}{l}\text { Rice bran } \\
\text { sourdough }\end{array}$ & $\begin{array}{c}\text { Yeast } \\
\text { Saccharomyces } \\
\text { cerevisiae }\end{array}$ & $\begin{array}{c}\text { Lactic Acid Bacteria } \\
\text { (LAB) }\end{array}$ \\
\hline Yeast (control) & $\sqrt{ }$ & $\mathrm{X}$ \\
Yeast + L. brevis & $\sqrt{ }$ & L. brevis \\
Yeast + L. & $\sqrt{ }$ & L. plantarum \\
plantarum & & \\
Yeast + L. & $\sqrt{ }$ & L. sanfranciscencis \\
sanfranciscencis & $\mathrm{X}$ & L. brevis \\
L. brevis & $\mathrm{X}$ & L. plantarum \\
L. plantarum & $\mathrm{X}$ & L. sanfranciscencis \\
L. sanfranciscencis & &
\end{tabular}

(X) - Indicates absent.

$(\sqrt{ })$ - Indicates present.

\subsubsection{Physicochemical analyses}

\subsubsection{1 $\mathrm{pH}$ and total titratable acidity (TTA) of rice bran sourdough}

$\mathrm{pH}$ and TTA were measured as described by Gül et al. (2005). Rice bran sourdough (10 g) was mixed with distilled water $(100 \mathrm{ml})$ to obtain a suspension. The $\mathrm{pH}$ value of the suspension was measured by using a $\mathrm{pH}$ meter. TTA was determined by titrating the suspension against $0.1 \mathrm{M} \mathrm{NaOH}$ to a final $\mathrm{pH}$ value of 8.5. The TTA was expressed as the amount of $\mathrm{NaOH}(\mathrm{ml})$ used for titration.

2.2.4.2 Extraction of organic acids, ethanol and sugar contents of the rice bran sourdough

The extraction method described by Lefebvre et al. (2002) was adopted. Sourdough (10 g) was homogenized with distilled deionized water $(60 \mathrm{ml})$ and the volume was adjusted to $100 \mathrm{ml}$. The sample was centrifuged (4000 $\left.\mathrm{x} g, 15^{\circ} \mathrm{C}, 15 \mathrm{~min}\right)$ and the supernatant was filtered under vacuum using Whatman filter paper $(0.45$ $\mu \mathrm{m})$. The filtrate $(10 \mathrm{ml})$ was mixed with distilled deionized water $(60 \mathrm{ml}), 5 \mathrm{ml}$ of $0.085 \mathrm{M}$ Carrez I solution (potassium II hexaferrocyanate) and $5 \mathrm{ml}$ of 0.25 M Carrez II solutions (zinc sulfate). The mixture was neutralized with $0.1 \mathrm{M} \mathrm{NaOH}$ until $\mathrm{pH} 8.0$ was reached. The volume was adjusted to $100 \mathrm{ml}$ with distilled deionized water and the solution was filtered through $0.45 \mu \mathrm{m}$ nylon membrane filter and transferred to HPLC vials. The filtrate was used for HPLC analysis of rice bran sourdough samples.

\subsubsection{HPLC analysis of rice bran sourdough}

Separation and quantification of rice bran sourdough sugar, lactic acid, acetic acid, and ethanol were determined according to the method described by Martínez-Anaya et al. (1993), with some modifications.
The concentration of sugars in the rice bran sourdough samples were analyzed using 1100 Series high performance liquid chromatography (Agilent, Germany). Detection was performed with a refractive index detector. Chromatographic separation was performed using ZORBAX carbohydrate analysis column $(4.6 \mathrm{~mm}$ x $150 \mathrm{~mm}$ ). The mobile phase was $80 \%$ acetonitrile and $20 \%$ water. The temperature of the column, flow rate, and injection volume were $30^{\circ} \mathrm{C}, 1.0 \mathrm{~mL} / \mathrm{min}$, and $20 \mu \mathrm{L}$, respectively.

Separation and quantification of lactic acid, acetic acid and ethanol were achieved with the same HPLC system and detector used for sugar analysis. Elution solvent was $0.0005 \mathrm{M} \mathrm{H}_{2} \mathrm{SO}_{4}$ at a flow rate of $0.7 \mathrm{ml} /$ min. Oven temperature was set at $40^{\circ} \mathrm{C}$ and $20 \mu \mathrm{l}$ of the sample filtrate was injected into an ion exclusion Aminex HPX-87H column (7.8 mm x $300 \mathrm{~mm})$. Fermentation quotient (FQ) of the rice bran sourdoughs was calculated as the molar ratio of lactate to acetate (Brandt et al., 2014).

\subsubsection{Preparation of bran sourdough bread}

Rice and wheat bran sourdough were prepared as described above (see section 2.2.3) using L. plantarum only. The rice and wheat bran sourdough, and nonfermented wheat and rice bran were used to substitute wheat flour at the level of $10 \mathrm{~g}$ per $100 \mathrm{~g}$ of flour.

Bran sourdough breads were produced by replacing $10 \%$ of the flour with an equivalent quantity of flour in the form of sourdough. The following five bread types were produced: 1$)$ control bread (100\% wheat flour), 2 ) rice bran bread (non-fermented rice bran), 3) wheat bran bread (non-fermented wheat bran), 4) rice bran sourdough bread (fermented rice bran) and, 5) wheat bran sourdough bread (fermented wheat bran). Other ingredients were wheat flour $(100 \mathrm{~g})$, water $(63 \mathrm{~g})$, dried instant yeast $(1.5 \mathrm{~g})$, sugar $(6 \mathrm{~g})$, salt $(1.5 \mathrm{~g})$ and shortening $(5 \mathrm{~g})$. The amounts of the ingredients used were based on the weight of wheat flour and wheat flour blends.

The wheat flour and other dry ingredients were mixed using a mixer (5K5SS Kitchen Aid spiral, St Joseph, Michigan). Water was added to the mixture followed by shortening. The dough was mixed at a low speed (Level 1) for 6 min followed by high speed (Level 3 ) mixing for another $6 \mathrm{~min}$. The dough was divided into $380 \mathrm{~g}$ portion and each portion was molded into round shape and allowed to proof at room temperature for 10 min. The dough was then punched, rolled, placed into a greased aluminum pan $(80 \times 190 \times 80 \mathrm{~mm})$ and proofed in a BERJAYA KR 105 proofer at $39^{\circ} \mathrm{C}$ and $60 \% \mathrm{RH}$ for $45 \mathrm{~min}$. The baking process was carried out at $200^{\circ} \mathrm{C}$ for 
30 min using an electric oven (Europa jet cook system, Valencia 688E, Malaysia). The bread loaves were cooled in open air at room temperature for $2 \mathrm{~h}$ before specific volume and texture analyses were carried out. Samples for crumb firmness were placed in zippered polypropylene bags and stored at room temperature for 6 days, crumb firmness was determined at 2 days intervals.

\subsubsection{Bread quality assessment}

\subsubsection{Specific volume, crumb and crust colour}

Loaf volume and specific volume were determined by the method described by Charoenthaikij et al. (2012). Loaf volume was measured by using the rape seed displacement method, while specific volume was calculated as loaf volume/weight. Specific volume was expressed as $\mathrm{cm}^{3} \mathrm{~g}^{-1}$.

Crumb and crust colour of the bread samples were determined using a chromatometer (Konica Minolta CR300 tristimulus, Osaka, Japan) calibrated with a white reference plate $(\mathrm{Y}=94.1 ; \mathrm{x}=0.3154 ; \mathrm{y}=0.3314)$. Readings were recorded as $\mathrm{L}^{*}$ (lightness), $\mathrm{a}^{*}$ (redness), $\mathrm{b}^{*}$ (yellowness).

\subsubsection{Crumb firmness}

Crumb firmness was measured at 0,2, 4 and 6 days of storage in order to assess the potential shelf life of the bread. The crumb firmness of the bread samples was determined according to AACC (74-09) standard method (AACC, 2000) using texture profile analysis test. The test was performed with a Stable Micro Systems TA-XT Plus Texture Analyzer (Godalming, England) equipped with a $36 \mathrm{~mm}$ diameter aluminum cylindrical probe. The bread was sliced into $25 \mathrm{~mm}$ thickness, and edges of the slices were cut off before measurement. The sliced bread was compressed to $40 \%$ deformation with a trigger force of $5 \mathrm{~g}$ at pre-test, test speed and post-test speed of $1 \mathrm{~mm} /$ $\mathrm{s}, 1.7 \mathrm{~mm} / \mathrm{s}$, and $10 \mathrm{~mm} / \mathrm{s}$, respectively. Firmness values were reported as the average of three measurements.

\subsection{Sensory evaluation}

The bread samples were evaluated by fifty untrained panelists, comprising of staff and students of the Faculty of Food Science and Technology, Universiti Putra Malaysia. The bread samples were scored using a 9-point hedonic scale, ranging from 1 (dislike extremely) to 9 (like extremely). Samples were evaluated for colour, flavour, texture, appearance, taste and overall acceptance.

\subsection{Statistical analysis}

Data were reported as mean values of three replicates for each sample except for sensory analysis. Statistical analysis was performed using Minitab version
16.0 software. Data obtained were subjected to one-way analysis of variance (ANOVA). Turkey's multiple comparison tests were used to determine the level of significant differences $(\mathrm{P}<0.05)$ between the samples.

\section{Results and discussion}

\subsection{Chemical composition of bran}

The chemical composition of rice and wheat bran used in this study is presented in Table 2. The results showed that the wheat bran used for the sourdough preparation had higher moisture (14.5\%), fibre (14\%) and carbohydrate (48\%) contents compared to rice bran. However, rice bran had higher ash $(8.5 \%)$ and fat contents $(18 \%)$, possibly due to the presence of germ in the bran (Moongngarm et al., 2012). The protein content of the wheat and rice bran was similar.

Table 2. Chemical composition of rice and wheat bran

\begin{tabular}{lcc}
\hline Chemical parameters & Rice bran $^{\mathrm{b}}$ & Wheat bran $^{\mathrm{a}, \mathrm{b}}$ \\
\hline Moisture content $(\% \mathrm{dm})$ & $7.2 \pm 0.2$ & $14.5^{\mathrm{a}}$ \\
Protein $(\% \mathrm{dm})$ & $11.7 \pm 1.2$ & $12.0^{\mathrm{a}}$ \\
Fat $(\% \mathrm{dm})$ & $18 \pm 3.8$ & $5.4^{\mathrm{b}}$ \\
Fibre $(\% \mathrm{dm})$ & $8.6 \pm 0.5$ & $14^{\mathrm{a}}$ \\
Ash $(\% \mathrm{dm})$ & $8.5 \pm 0.2$ & $6^{\mathrm{a}}$ \\
Carbohydrate $(\% \mathrm{dm})$ & $45.9 \pm 1.7$ & $48.1^{\mathrm{b}}$ \\
\hline
\end{tabular}

${ }^{\mathrm{a}}$ Data are based on information provided on the label.

${ }^{\mathrm{b}}$ Data determined by author.

${ }^{\mathrm{a}, \mathrm{b}}$ Combination of data provided on the label and data determined by author

\subsection{Physicochemical properties}

\subsection{1 $\mathrm{pH}$ and total titratable acidity (TTA) of rice} bran sourdough

The results of $\mathrm{pH}$ profile of the rice bran sourdough showed that there was no significant difference between the sample fermented with yeast only, and those fermented with a mixed culture of yeast and $\mathrm{LAB}$, with values in the range of 5.82-5.88 (Table 3 ). This could be due to inhibition of yeast activities as a result of competition between LAB and yeast for sugar substrate during the fermentation process (Skinner and Leathers, 2004). However, sourdough fermented with L. brevis, $L$. plantarum, and L. sanfranciscencis had significantly $(\mathrm{p}<$ 0.05) lower $\mathrm{pH}$ value (4.09) compared with those fermented with a combination of yeast and LAB strains. This result was in agreement with the findings of Clarke et al. (2002), who reported higher $\mathrm{pH}$ value for sourdough fermented with mixed strains starter culture. On the other hand, the $\mathrm{pH}$ of the L. brevis, L. plantarum, and $L$. sanfranciscencis fermented rice bran sourdough was not significantly different from each other, although bran fermented with $L$. plantarum had the lowest $\mathrm{pH}$ value among the sourdough samples. The $\mathrm{pH}$ values 
(4.09-4.11) reported for L. brevis, L. plantarum, and $L$. sanfranciscencis starter culture fermented rice bran sourdough reported in this study are within the range of $\mathrm{pH}$ (4.0-4.3) reported for wheat dough fermented with $L$. plantarum, and L. brevis (Clarke et al., 2002).

The TTA of the yeast fermented sourdough was higher (11.23), but not significantly different $(p<0.05)$ from that of the sourdough samples fermented with mixed starter culture strains (10.60-11.10) (Table 3). However, rice bran sourdough fermented with $L$. brevis had the highest TTA value (21.8) followed by the sourdough fermented with L. plantarum (21.2).

Table 3. $\mathrm{pH}$ and titratable acidity (TTA) of rice bran sourdoughs fermented with yeast and/or lactic acid bacteria

\begin{tabular}{lcc}
\hline Sourdough & $\mathrm{pH}$ & TTA \\
\hline Yeast (control) & $5.88 \pm 0.02^{\mathrm{a}}$ & $11.23 \pm 0.29^{\mathrm{c}}$ \\
Yeast + L. brevis & $5.85 \pm 0.02^{\mathrm{a}}$ & $11.10 \pm 0.27^{\mathrm{c}}$ \\
Yeast + L. plantarum & $5.83 \pm 0.01^{\mathrm{a}}$ & $10.77 \pm 0.31^{\mathrm{c}}$ \\
Yeast + L. sanfranciscencis $^{\mathrm{a}}$ & $5.82 \pm 0.02^{\mathrm{a}}$ & $10.60 \pm 0.27^{\mathrm{c}}$ \\
L. brevis & $4.10 \pm 0.02^{\mathrm{c}}$ & $21.83 \pm 0.65^{\mathrm{a}}$ \\
L. plantarum $_{\text {L. sanfranciscencis }}$ & $4.09 \pm 0.01^{\mathrm{c}}$ & $21.20 \pm 0.10^{\mathrm{ab}}$ \\
\hline
\end{tabular}

The lower $\mathrm{pH}$ and higher TTA values recorded for rice bran sourdough fermented with $L$. brevis, $L$. plantarum, and $L$. sanfranciscencis starter culture compared with those fermented with mixed strains of $\mathrm{LAB}$ and yeast could be because the presence of yeast becomes negative at long fermentation period, thus, $\mathrm{pH}$ and TTA of dough depends mainly on LAB (Chavan and Chavan, 2011). It could also be due to competition between baker's yeast and LAB for carbohydrate source (Gurbuz et al., 2010).

\subsubsection{Organic acids, ethanol and sugar contents of} the rice bran sourdough

The organic acids determined in this study were lactic acid and acetic acid. These acids are important for flavour and taste of sourdough bread (Hansen and Hansen, 1996). The amount of lactic acid produced in the sourdough fermented with L. brevis, L. plantarum, and $L$. sanfranciscencis was higher than that in other samples (Table 4). Higher lactic acid content recorded for the sourdough fermented with $L$. brevis, $L$. plantarum, and L. sanfranciscencis starter culture could be ascribed to improved activities of LAB, which resulted in the rapid production of lactic acid in the sourdoughs. This result was in agreement with the findings of Gurbuz et al. (2010), who reported that LAB grows and produce lactic acid more slowly in mixtures containing yeasts than in pure culture. Sourdough with high acid will have improved proteolysis and protein solubility. This will, in turn, lead to improve texture in bread made with bran sourdough (Katina et al., 2006). This indicates that bread made from rice bran sourdough with high to moderate acid content will have better textural properties. The trend of lactic acid values recorded for rice bran sourdough in this study was incongruent with that of Collar (1996).

Mixed culture of $L$. sanfranciscencis and yeast produced the highest amount of acetic acids in the sourdoughs (Table 4). This result is in line with the result of Vollmar and Meuser (1992), who reported that acetic acid production was optimal when $L$. sanfranciscencis was associated with $S$. cerevisiae, while fermentation with yeast did not produce the same effect. In contrary, Colla (1996) and Merseburger et al. (2005), reported that LAB grows and produce acetic acids slowly in a mixed culture of $\mathrm{LAB}$ and yeast. Acetic acid has an antimicrobial effect on rope-producing Bacillus and antimould effect on sourdough bread (Rosenquist and Hansen, 1998).

Sourdough fermented with yeast, and mixed culture had higher concentrations of ethanol compared with those fermented with $L$. brevis, L. plantarum, and $L$. sanfranciscencis (Table 4). This could be due to the effect of yeast fermentation on carbohydrate, in which glucose is converted into ethanol (Gurbuz et al., 2010). This result is in agreement with the previous report on headspace flavour profile of dough, in which ethanol is the most prominent compound in dough fermented with yeast while diacetyl is prominent in dough fermented with LAB (Colla, 1996). Sourdough fermented with $L$. plantarum had the highest fermentation quotient (FQ) value (3.88) compared with the other samples (Table 4). This value was close to the recommended FQ value (4.00) for sourdough (Spicher and Stephen, 1999).

The soluble carbohydrate contents of rice bran sourdough; glucose, maltose, fructose and sucrose ranged from $0.35-1.11 \mathrm{~g} / 100 \mathrm{~g}, 0.48-1.06 \mathrm{~g} / 100 \mathrm{~g}, 0.72-$ $1.34 \mathrm{~g} / 100 \mathrm{~g}$ and $0.55-1.32 \mathrm{~g} / 100 \mathrm{~g}$, respectively (Table 5 ). Rice bran sourdough fermented with yeast (control sample) had the highest glucose $(1.1 \mathrm{~g} / 100 \mathrm{~g})$ and maltose content $(1.06 \mathrm{~g} / 100 \mathrm{~g})$ compared to the sourdoughs fermented with mixed culture or L. brevis, $L$. plantarum, and L. sanfranciscencis. This could be because yeasts and LAB have different kinetics for soluble carbohydrate uptake (Gurbuz et al., 2010). This observation was in agreement with the report of Colla et al. (1996). The fructose content of all the sourdough samples was not significantly different $(p>0.05)$. This is possibly because both yeast and LAB have similar kinetics for fructose uptake and fermentation (Koca et al., 2002; Gurbuz, 2010). There were no significant 
Table 4. Organic acids and ethanol contents of rice bran sourdoughs fermented with yeast and/or lactic acid bacteria

\begin{tabular}{lcccc}
\hline \multirow{2}{*}{ Rice bran sourdoughs } & \multicolumn{3}{c}{ Concentration $(\mathrm{g} / 100 \mathrm{~g})$} & \multirow{2}{*}{ Fermentation Quotient (FQ) } \\
\cline { 2 - 4 } & Lactic acid & Acetic acid & Ethanol & 1.08 \\
\hline Yeast (control) & $0.13 \pm 0.01^{\mathrm{b}}$ & $0.12 \pm 0.05^{\mathrm{c}}$ & $0.95 \pm 0.14^{\mathrm{ab}}$ & - \\
Yeast + L. brevis & $0.07 \pm 0.00^{\mathrm{c}}$ & $0.05 \pm 0.00^{\mathrm{d}}$ & $1.17 \pm 0.09^{\mathrm{a}}$ & 0.74 \\
Yeast + L. plantarum & $0.14 \pm 0.01^{\mathrm{b}}$ & $0.19 \pm 0.03^{\mathrm{b}}$ & $1.01 \pm 0.19^{\mathrm{a}}$ & 0.39 \\
Yeast + L. sanfranciscencis & $0.11 \pm 0.00^{\mathrm{b}}$ & $0.28 \pm 0.02^{\mathrm{a}}$ & $0.93 \pm 0.08^{\mathrm{ab}}$ & - \\
L. brevis & $0.32 \pm 0.03^{\mathrm{a}}$ & $\mathrm{n} . \mathrm{d}$ & $0.40 \pm 0.11^{\mathrm{cd}}$ & 3.88 \\
L. plantarum & $0.31 \pm 0.03^{\mathrm{a}}$ & $0.08 \pm 0.02^{\mathrm{d}}$ & $0.44 \pm 0.08^{\mathrm{cd}}$ & - \\
L. sanfranciscencis & $0.29 \pm 0.06^{\mathrm{a}}$ & n.d & $0.74 \pm 0.19^{\mathrm{bc}}$ & \\
\hline
\end{tabular}

Values in the same column with different superscript letters are significantly different $(\mathrm{p}<0.05)$. n.d - indicates not detected.

Values are means \pm standard deviations of triplicate analyses.

Table 5. Sugar contents of rice bran sourdoughs $(\mathrm{g} / 100 \mathrm{~g})$ fermented with yeast and/or lactic acid bacteria

\begin{tabular}{lcccc}
\hline Rice Bran Sourdoughs & Glucose & Maltose & Fructose & Sucrose \\
\hline Yeast (control) & $1.11 \pm 0.05^{\mathrm{a}}$ & $1.06 \pm 0.16^{\mathrm{c}}$ & $0.72 \pm 0.01^{\mathrm{e}}$ & $0.54 \pm 0.03^{\mathrm{g}}$ \\
Yeast + L. brevis $^{\mathrm{a}}$ & $1.02 \pm 0.04^{\mathrm{a}}$ & $1.00 \pm 0.05^{\mathrm{c}}$ & $0.80 \pm 0.02^{\mathrm{e}}$ & $0.69 \pm 0.01^{\mathrm{g}}$ \\
Yeast + L. plantarum $_{\text {Yeast }+ \text { L. sanfranciscencis }}$ & $0.93 \pm 0.03^{\mathrm{a}}$ & $0.82 \pm 0.03^{\mathrm{c}}$ & $1.04 \pm 0.02^{\mathrm{e}}$ & $0.67 \pm 0.01^{\mathrm{g}}$ \\
L. brevis $_{\text {L. plantarum }}$ & $0.43 \pm 0.02^{\mathrm{b}}$ & $0.79 \pm 0.01^{\mathrm{c}}$ & $0.94 \pm 0.04^{\mathrm{e}}$ & $0.74 \pm 0.05^{\mathrm{g}}$ \\
L. sanfranciscencis & $0.38 \pm 0.06^{\mathrm{b}}$ & $0.48 \pm 0.01^{\mathrm{d}}$ & $1.34 \pm 0.05^{\mathrm{e}}$ & $1.07 \pm 0.06^{\mathrm{f}}$ \\
\hline
\end{tabular}

Values are means \pm standard deviations of triplicate analyses.

Mean values in the same column with different superscript letters are significantly different $(\mathrm{p}<0.05)$.

Table 6. Specific volume, crumb and crust colour of rice and wheat bran supplemented breads

\begin{tabular}{|c|c|c|c|c|c|c|c|}
\hline \multirow{2}{*}{ Bread sample } & \multirow{2}{*}{$\begin{array}{c}\text { Specific } \\
\text { Volume }\left(\mathrm{cm}^{3} / \mathrm{g}\right)\end{array}$} & \multicolumn{3}{|c|}{ Crumb } & \multicolumn{3}{|c|}{ Crust } \\
\hline & & $\mathrm{L}^{*}$ & $a^{*}$ & $\mathrm{~b}^{*}$ & $\mathrm{~L}^{*}$ & $\mathrm{a}^{*}$ & $\mathrm{~b}^{*}$ \\
\hline \multirow{2}{*}{ Control (no bran) } & \multirow{2}{*}{$4.85 \pm 0.17^{\mathrm{f}}$} & $68.34 \pm$ & $-0.87 \pm$ & $8.02 \pm$ & $45.37 \pm$ & $14.85 \pm$ & $25.75 \pm$ \\
\hline & & $1.03^{\mathrm{ab}}$ & $0.10^{\mathrm{d}}$ & $0.86^{\mathrm{f}}$ & $3.23^{\mathrm{g}}$ & $0.97^{\mathrm{h}}$ & $4.07^{\mathrm{i}}$ \\
\hline \multirow{2}{*}{ Rice bran } & \multirow{2}{*}{$4.24 \pm 0.07^{\mathrm{g}}$} & $70.64 \pm$ & $-0.77 \pm$ & $12.39 \pm$ & $47.81 \pm$ & $14.20 \pm$ & $27.74 \pm$ \\
\hline & & $0.20^{\mathrm{a}}$ & $0.08^{\mathrm{d}}$ & $0.60^{\mathrm{e}}$ & $3.94^{\mathrm{g}}$ & $0.48^{\mathrm{h}}$ & $2.96^{\mathrm{i}}$ \\
\hline \multirow{2}{*}{ Wheat bran } & \multirow{2}{*}{$3.74 \pm 0.12^{\mathrm{h}}$} & $67.82 \pm$ & $1.21 \pm$ & $13.98 \pm$ & $44.04 \pm$ & $13.25 \pm$ & $23.53 \pm$ \\
\hline & & $1.77^{\mathrm{ab}}$ & $0.22^{\mathrm{c}}$ & $0.47^{\mathrm{e}}$ & $3.32^{\mathrm{g}}$ & $0.84^{\mathrm{h}}$ & $3.68^{\mathrm{i}}$ \\
\hline \multirow{2}{*}{ Rice bran sourdough } & \multirow{2}{*}{$4.65 \pm 0.13^{\mathrm{f}}$} & $70.10 \pm$ & $-0.87 \pm$ & $12.41 \pm$ & $45.92 \pm$ & $14.80 \pm$ & $26.78 \pm$ \\
\hline & & $3.11^{\mathrm{a}}$ & $0.14^{\mathrm{d}}$ & $1.52^{\mathrm{e}}$ & $1.47^{\mathrm{g}}$ & $0.02^{\mathrm{h}}$ & $2.96^{\mathrm{i}}$ \\
\hline \multirow{2}{*}{ Wheat bran sourdough } & \multirow{2}{*}{$4.32 \pm 0.03^{\mathrm{g}}$} & $64.45 \pm$ & $1.44 \pm$ & $12.19 \pm$ & $45.20 \pm$ & $14.19 \pm$ & $25.03 \pm$ \\
\hline & & $1.04^{\mathrm{b}}$ & $0.06^{\mathrm{c}}$ & $0.31^{\mathrm{e}}$ & $1.72^{\mathrm{g}}$ & $0.53^{\mathrm{h}}$ & $1.91^{\mathrm{i}}$ \\
\hline
\end{tabular}

Values are means \pm standard deviations of triplicate analyses.

Mean values in the same column with different superscript letters are significantly different $(\mathrm{p}<0.05)$.

Table 7. Sensory analysis of Rice and wheat bran sourdough bread

\begin{tabular}{lccccc}
\hline Quality parameters & $\begin{array}{c}\text { Wheat flour } \\
\text { (control) }\end{array}$ & Rice bran & Wheat bran & $\begin{array}{c}\text { Rice bran } \\
\text { sourdough }\end{array}$ & $\begin{array}{c}\text { Wheat bran } \\
\text { sourdough }\end{array}$ \\
\hline Colour & $7.24 \pm 0.05^{\mathrm{a}}$ & $7.09 \pm 0.07^{\mathrm{b}}$ & $6.87 \pm 0.04^{\mathrm{c}}$ & $7.36 \pm 0.18^{\mathrm{a}}$ & $6.82 \pm 0.05^{\mathrm{c}}$ \\
Flavour & $7.37 \pm 0.11^{\mathrm{a}}$ & $6.02 \pm 0.09^{\mathrm{d}}$ & $6.55 \pm 0.04^{\mathrm{c}}$ & $6.62 \pm 0.11^{\mathrm{bc}}$ & $6.78 \pm 0.03^{\mathrm{b}}$ \\
Texture & $7.19 \pm 0.05^{\mathrm{a}}$ & $6.59 \pm 0.03^{\mathrm{c}}$ & $6.12 \pm 0.03^{\mathrm{d}}$ & $7.11 \pm 0.05^{\mathrm{a}}$ & $6.72 \pm 0.02^{\mathrm{b}}$ \\
Appearance & $7.36 \pm 0.10^{\mathrm{a}}$ & $7.19 \pm 0.03^{\mathrm{b}}$ & $7.12 \pm 0.03^{\mathrm{b}}$ & $7.37 \pm 0.04^{\mathrm{a}}$ & $7.25 \pm 0.04^{\mathrm{ab}}$ \\
Taste & $7.30 \pm 0.05^{\mathrm{a}}$ & $6.63 \pm 0.09^{\mathrm{b}}$ & $6.55 \pm 0.09^{\mathrm{b}}$ & $7.24 \pm 0.03^{\mathrm{a}}$ & $7.17 \pm 0.05^{\mathrm{a}}$ \\
Overall acceptability & $7.24 \pm 0.05^{\mathrm{a}}$ & $6.43 \pm 0.02^{\mathrm{c}}$ & $6.39 \pm 0.02^{\mathrm{c}}$ & $7.25 \pm 0.02^{\mathrm{a}}$ & $6.94 \pm 0.07^{\mathrm{b}}$ \\
\hline
\end{tabular}

Values are mean \pm standard deviation $(n=50)$.

Mean values along the same row with different alphabet $(\mathrm{s})$ are significantly different $(\mathrm{p}<0.05)$. 
differences $(p>0.05)$ in the sucrose content of the control sourdough and the sourdough produced from a mixed culture, however, significant differences $(p<0.05)$ existed between the sucrose contents of mixed culture and $L$. brevis, $L$. plantarum, and L. sanfranciscencis fermented sourdoughs. This could be due to invertase hydrolysis of sucrose into glucose and fructose by yeast (Aksu and Kutsal, 1986), which leads to rapid sucrose depletion in the sourdough fermented with mixed culture and the control sample (Martínez -Anaya, 1996).

Among the starter cultures, L. plantarum proved to be the most effective for rice bran sourdough production in terms of acidity ( $\mathrm{pH}$ and TTA) and fermentation quotient, which are important parameters for assessing sourdough quality. Thus, L. plantarum was subsequently used to ferment rice and wheat bran for sourdough bread production.

\subsection{Bread quality}

\subsubsection{Specific volume, crumb and crust colour}

Bread samples substituted with fermented and nonfermented rice and wheat bran had reduced specific volume when compared with 100\% wheat bread (control) (Table 6). However, the specific volume of rice $\left(4.65 \mathrm{~cm}^{3} / \mathrm{g}\right)$ and wheat bran sourdough bread $(4.32$ $\left.\mathrm{cm}^{3} / \mathrm{g}\right)$ was significantly higher than that of rice $(4.24$ $\left.\mathrm{cm}^{3} / \mathrm{g}\right)$ and wheat bran $\left(3.74 \mathrm{~cm}^{3} / \mathrm{g}\right)$ bread. The specific volume of rice bran sourdough bread was not significantly different $(p>0.05)$ from that of the control bread (Table 6), while the specific volume of the wheat bran sourdough bread was significantly $(p<0.05)$ lower than the control (Table 6). In contrast to this result, Corsetti et al. (2000), reported higher volume for bread produced with LAB and $S$. cerevisiae association than that of bread produced with $S$. cerevisiae alone. The differences in the specific volume of the sourdough substituted bread reported in this study could be due to differences in the fibre content of the bran (Table 2). Higher specific volume recorded for bran sourdough substituted bread compared to non-fermented bran substituted bread samples could be due to increased retention of $\mathrm{CO}_{2}$ in the bread dough as a result of $\mathrm{LAB}$ acidification, which enhanced the capacity of gluten to retain $\mathrm{CO}_{2}$ (Gobbetti et al., 1995). This indicates that rice bran sourdough does not have a negative effect on the bread volume. In line with this observation, Salmenkallio -Marttila et al. (2001) also reported that the use of fermented cereal bran in bread making has a positive influence on bread volume.

As shown in Table 6, the addition of cereal bran to wheat flour darkens the colour of the wheat bran bread crumb. However, rice bran sourdough bread had the highest crumb lightness $\left(L^{*}\right)$ value followed by that of the rice bran bread. According to Gallagher et al. (2003), rice-based bread tends to have a lighter colour than wheat bread. The light colour of rice bran might be due to the presence of bound phenolics in rice (Min et al., 2012). The lower $L^{*}$ values recorded for wheat bran bread crumb could possibly be due to the effect of Maillard browning (Kent and Evers, 1994). Negative redness $\left(a^{*}\right)$ values recorded for the control and the rice bran substituted bread samples indicates that the colour of the bread crumb was tending towards green than red colour. This could be due to the influence of the various ingredients on the bread crumb. However, bread substituted with wheat bran had positive redness $\left(a^{*}\right)$ value. The presence of carotenoid pigments in wheat bran could be responsible for the redness of the wheat bran bread crumb (Toufeili et al., 1999). There were no significant differences $(p>0.05)$ in the crust colour of all the five bread samples in terms of lightness $\left(\mathrm{L}^{*}\right)$, redness $\left(a^{*}\right)$ and yellowness $\left(b^{*}\right)$.

\subsubsection{Crumb firmness}

Substitution of wheat flour with non-fermented rice and wheat bran resulted in increased bread crumb firmness, whereas, substitution with rice and wheat bran sourdough reduced crumb firmness. The addition of rice and wheat bran sourdough to wheat flour was effective in improving crumb texture of the bread samples (Figure 1). Changes in the firmness of the crumb after storage could be due to different staling processes occurring in the bread samples. Among the fresh (0 day storage) bread samples, wheat bran bread had the hardest crumb followed by rice bran bread. The mean crumb hardness of rice and wheat bran sourdough bread was similar to that of the control bread but lower than that of the nonfermented bran substituted bread (Figure 1). This result is also confirmed by the higher specific volume of sourdough bread samples than the bran substituted breads (Table 6). Higher crumb hardness recorded for the non-fermented bran substituted breads could be

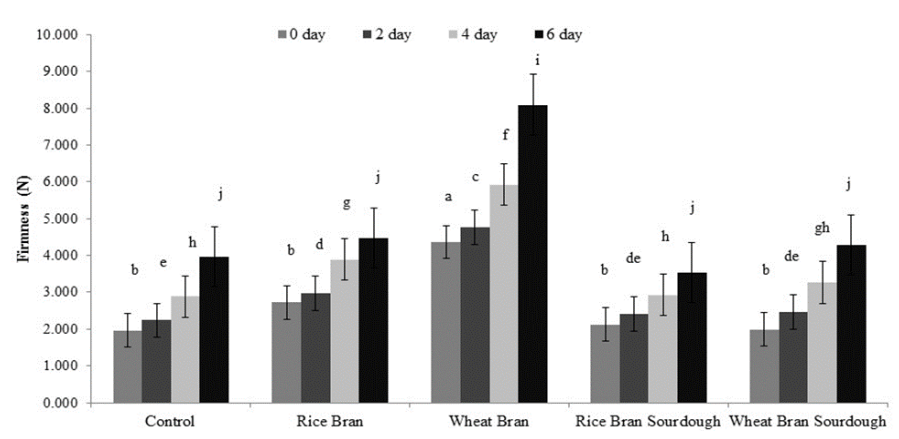

Figure 1. Crumb firmness values of bread loaves produced from $100 \%$ wheat flour (control), wheat flour supplemented with unfermented rice and wheat bran, and rice and wheat bran sourdough during a 6 days storage period. Bars with different alphabets within the different bread types are significantly different $(\mathrm{P}<0.05)$. 
probably due to the high fibre content of rice and wheat bran (Table 2) and thus, higher water absorption capacity.

After 2 days of storage, rice bran sourdough bread was significantly softer than the control bread. This could be because sourdough fermentation plays important role in preserving bread freshness by influencing the loaf moisture redistribution during storage, through acidification development (Corsetti et al., 2000). The protein solubility and proteolysis enhancement during sourdough fermentation process could also modify the gluten network, thereby, affecting the texture of bread (Armero and Collar, 1997).

After 6 days of storage, control bread was firmer than rice bran sourdough bread. Indicating that rice bran sourdough bread maintained its freshness during the 6 days period of storage. This could be due to the inhibitory effect of sourdough on bread staling. Many studies have reported the ability of sourdough in delaying staling process in wheat and other gluten bread (Barber et al., 1992; Corsetti et al., 1998; Corsetti et al., 2000). Moore et al. (2008), also reported that $L$. plantarum can be used to improve the quality and shelf life of bread. However, bread firmness does not only depend on starter culture but also depends on other physicochemical factors (Corsetti et al., 1998).

\subsection{Sensory analysis}

The mean sensory scores of the bread samples are presented in Table 7 . The sensory analysis result showed that all the sensory attributes were lowest for nonfermented bran substituted bread compared to the bran sourdough bread. The highest score for almost all the sensory attributes was observed in rice bran sourdough bread and control (Table 7). The darker colour of the wheat bran and wheat bran sourdough substituted bread could be due to the inherent colour of wheat bran. The sensory scores for the colour of the bread were in conformity with that of the instrumental analysis (Table 6). Reduced sensory score recorded for the flavour of rice bran and rice bran sourdough bread might be attributed to the unfamiliarity of the panelist with rice bran odour. Generally, rice bran sourdough bread was more acceptable than rice and wheat bran substituted bread, and wheat bran sourdough bread in terms of colour, texture, appearance, taste and overall acceptability.

\section{Conclusion}

The results of this study showed that rice bran sourdough produced by Lactobacillus plantarum had low $\mathrm{pH}$, moderate sugar contents, high TTA, and fermentation quotient compared to sourdough fermented with a mixed culture of yeast and $\mathrm{LAB}$ or a single strain of yeast/other LAB. Rice bran sourdough substituted bread had higher specific volume, longer shelf life and best sensorial scores for colour, appearance and overall acceptability than the control bread and other bran and sourdough substituted bread. This study has demonstrated the potential of $L$. plantarum fermented rice bran sourdough for sourdough bread production. The use of rice bran sourdough for bread making would add value to rice bran and increase its utilization in riceproducing countries, and also provide additional income for rice milling industries.

\section{Conflict of Interest}

Authors have no conflict of interest.

\section{Acknowledgments}

The research work was funded by Universiti Putra Malaysia and Padiberas Nasional Berhad (Grant No. 6360600). Bolarinwa, I.F., is grateful to Universiti Putra Malaysia (UPM), The World Academy of Science (TWAS) for postdoctoral fellowship award, and to Ladoke Akintola University of Technology, Nigeria, for her release for the fellowship.

\section{References}

AACC. (2000). Approved methods of Analysis, $10^{\text {th }} \mathrm{ed}$. Minnesota, USA: American Association of Cereal Chemists.

Aksu, Z. and Kutsal, T. (1986). Lactic acid production from molasses utilizing Lactobacillus delbrueckii and invertase together. Biotechnology Letters, 8(3), 157-160. https://doi.org/10.1007/BF01029370

AOAC. (1995). Official methods of analysis. 15th ed. Washington DC, USA: Association of Official Analytical Chemists.

Armero, E. and Collar, C. (1997). Texture properties of formulated wheat doughs. Relationships with dough and bread technological quality. Zeitschrift fur Lebensmittel Untersuchung und Forschung, 204, 136 -145 .

Barber, B., Ortola, C., Barber, S. and Fernández, F. (1992) Storage of packaged white bread III. Effects of sourdough and addition of acids on bread characteristics. Zeitschrift fur Lebensmittel Untersuchung und Forschung, 194(5), 442-449. https://doi.org/10.1007/BF01197726

Brandt, M.J., Hammes, W.P. and Gänzle, M. G. (2014). Effects of process parameters on growth and Metabolism of Lactobacillus sanfranciscensis and 
Candida humilis during rye sourdough fermentation. European Food Research and Technology, 218(4), 333-338. https://doi.org/10.1007/s00217-003-0867-0

Charoenthaikij, P., Jangchud, K., Jangchud, A., Prinyawiwatkul, W. and No, H.K. (2012). Composite wheat-germinated brown rice flour: selected physicochemical properties and bread application. International Journal of Food Science and Technology, 47(1), 75-82. https:// doi.org/10.1111/j.1365-2621.2011.02809.x

Chavan, R.S. and Chavan, S.R. (2011). Sourdough Technology-A Traditional Way for Wholesome Foods: A Review. Comprehensive Reviews in Food Science and Food Safety, 10(3) , 170-183. https:// doi.org/10.1111/j.1541-4337.2011.00148.x

Chinma, C.E., Ilowefah, M. and Muhammad, K. (2014). Optimization of rice bran fermentation conditions enhanced by baker's yeast for extraction of protein concentrate. Nigerian Food Journal, 32(1), 126-132. https://doi.org/10.1016/S0189-7241(15)30105-3

Chinma, C.E., Ramakrishnan, Y., Ilowefah, M., HanisSyazwani, M. and Muhammad, K. (2015). Properties of cereal brans: A review. Cereal Chemistry, 92(1), 1 -7. https://doi.org/10.1094/CCHEM-10-13-0221-RW

Clarke, C.I., Schober, T.J. and Arendt, E.K. (2002). Effect of Single Strain and Traditional Mixed Strain Starter Cultures on Rheological Properties of Wheat Dough and on Bread Quality. Cereal Chemistry, 79 (5), 640-647. https://doi.org/10.1094/ CCHEM.2002.79.5.640

Coda, R., Kärki, I., Nordlund, E., Heiniö, R-L., Poutanen, K. and Katina, K. (2014). Influence of particle size on bioprocess induced changes on technological functionality of wheat bran. Food Microbiology, 37, 69-77. https://doi.org/10.1016/ j.fm.2013.05.011

Coda, R., Katina, K. and Rizzello, C.G. (2015). Bran bioprocessing for enhanced functional properties. Current Opinion in Food Science, 1, 50-55. https:// doi.org/10.1016/j.cofs.2014.11.007

Collar, C. (1996). Biochemical and technological assessment of the metabolism of pure and mixed cultures of yeast and lactic acid bacteria in bread making applications. Food Science and Technology International, 2(6), 349-367. https:// doi.org/10.1177/108201329600200601

Corsetti, A., Gobbetti, M., Balestrieri, F., Paoletti, F., Russi, L. and Rossi, J. (1998). Sourdough lactic acid bacteria effects on bread firmness and staling. Journal of Food Science, 63(2), 347-351. https:// doi.org/10.1111/j.1365-2621.1998.tb15739.x

Corsetti, A., Gobbetti, M., De Marco, B., Balestrieri, F., Paoletti, F., Russi, L. and Rossi, J. (2000). Combined
Effect of Sourdough Lactic Acid Bacteria and Additives on Bread Firmness and Staling. Journal of Agricultural and Food Chemistry, 48(7), 3044-3051. https://doi.org/10.1021/jf990853e

Farahmand, E., Razavi, S.H., Yarmand, M.S. and Morovatpour, M. (2015). Development of Iranian rice-bran sourdough breads: physicochemical, microbiological and sensorial characteristics during storage period. Quality Assurance and Safety of Crops and Foods, 7(3), 295-303. https:// doi.org/10.3920/QAS2013.0334

Gobbetti, M., Corsetti, A. and Rossi, J. (1995). Interaction between lactic acid bacteria and yeasts in sourdough using a rheofermentometer. World Journal Microbiology Biotechnology, 11(6), 625630. https://doi.org/10.1007/BF00361004

Gallagher, E., Gormley, T.R. and Arendt, E.K. (2003). Crust and crumb characteristics of gluten free breads. Journal of Food Engineering, 56(2-3), 153161. https://doi.org/10.1016/S0260-8774(02)00244-3

Gobbetti, M., Rizzello, C.G., Di Cagno, R., De Angelis, M. (2014). How the sourdough may affect the functional features of leavened baked goods. Food Microbiology, 37, 30-40. https://doi.org/10.1016/ j.fm.2013.04.012

Gómez, M., Jiménez, S., Ruiz, E. and Oliete, B. (2011). Effect of extruded wheat bran on dough rheology and bread quality. LWT - Food Science and Technology, 44(10), 2231-2237. https:// doi.org/10.1016/j.lwt.2011.06.006

Gül, H., Özçelik, S., Sa gdıç, O. and Certel, M. (2005). Sourdough bread production with lactobacilli and $S$. cerevisiae isolated from sourdoughs. Process Biochemistry, 40(2), 691-697. https:// doi.org/10.1016/j.procbio.2004.01.044

Gurbuz, O., Gocmen, D., Ozmen, N. and Dagdelen, F. (2010). Effects of yeast, fermentation time, and preservation methods on tarhana. Preparative Biochemistry and Biotechnology, 40(4), 263-275. https://doi.org/10.1080/10826068.2010.488987

Hansen, A. and Hansen, B. (1996). Flavour of sourdough wheat bread crumb. Zeitschrift fur LebensmittelUntersuchung und Forschung, 202(3), 244-249. https://doi.org/10.1007/BF01263548

Katina, K., Salmenkallio-Marttila, M., Partanen, R., Forssell, P.and Autio, K. (2006). Effects of sourdough and enzymes on staling of high-fibre wheat bread. Lebensmittel-Wissenschaft undTechnologie, 39(5), 479-491. https:// doi.org/10.1016/j.lwt.2005.03.013

Katina K., Juvonen R., Laitila A., Flander L., Nordlund E., Kariluoto S. and Poutanen K. (2012). Fermented wheat bran as a functional ingredient in baking. 
Cereal Chemistry, 89(2), 126-134. https:// doi.org/10.1094/CCHEM-08-11-0106

Kent, N.L. and Evers, A.D. (1994). Technology of cereals: An introduction for students of food science and Agriculture. Oxford: Pergamon.

Koca, A.F., Yazici, F. and Anil, M. (2002). Utilization of soy yogurt in Tarhana production. European Food Research and Technology, 215(4), 293-297. https:// doi.org/10.1007/s00217-002-0568-0

Lefebvre, D., Gabriel, V., Vayssier, Y. and FontagneFaucher, C. (2002). Simultaneous HPLC determination of sugars, organic acids and ethanol in sourdough process. LWT- Food Science and Technology, 35(5), 407-414. https://doi.org/10.1006/ fstl.2001.0859

Martínez-Anaya, M.A., Pitarch, B. and Benedito de Barber, C. (1993). Biochemical characteristics and bread making performance of freeze-dried wheat sourdough starters. Zeitschrift fur LebensmittelUntersuchung und Forschung, 196(4), 360-365. https://doi.org/10.1007/BF01197936

Martínez -Anaya, M.A. (1996). Enzymes and bread flavour. Journal of Agriculture and Food Chemistry, 44(9), 2469-2480. https://doi.org/10.1021/jf960020d

Merseburger, T., Ehret, A., Geiges, O., Baumann, B. and Schmidt-Lorenz, W. (2005). Microbiology of Dough Preparation VII. Production and Use of Preferments to Produce Wheat Bread. Mitteilungen Aus Dem Gebiete Der Lebensmittel-Untersuchungen Un Hygien, 86, 304-324.

Min, B., Gu, L., McClung, A.M., Bergman, C.J. and Chen, M.H. (2012). Free and bound total phenolic concentrations, antioxidant capacities, and profiles of proanthocyanidins and anthocyanins in whole grain rice (Oryza sativa L.) of different bran colours. Food Chemistry, 133(3), 715-722. https://doi.org/10.1016/ j.foodchem.2012.01.079

Moongngarm, A., Daomukda, N. and Khumpik, S. (2012). Chemical Compositions, Phytochemicals, and Antioxidant Capacity of Rice Bran, Rice Bran Layer, and Rice Germ. APCBEE Procedia, 2(2012), 73-79. https://doi.org/10.1016/j.apcbee.2012.06.014

Moore, M.M., Bello, F.D. and Arendt, E.K. (2008). Sourdough fermented by Lactobacillus plantarum FST 1.7 improves the quality and shelf life of glutenfree bread. European Food Research and Technology, 226(6), 1309-1316. https:// doi.org/10.1007/s00217-007-0659-z

Noort, M.W., Van Haaster, D., Hemery, Y., Schols, H.A. and Hamer, R.J. (2010). The effect of particle size of wheat bran fractions on bread quality - evidence for fibre-protein interactions. Journal of Cereal Science, 52(1), 59-64. https://doi.org/10.1016/ j.jcs.2010.03.003

Poutanen, K., Flander, L. and Katina, K. (2009). Sourdough and cereal fermentation in a nutritional perspective. Food Microbiology, 26, 693-699. https://doi.org/10.1016/j.fm.2009.07.011

Rosenquist, H. and Hansen, Å. (1998). The antimicrobial effect of organic acids sourdough and nisin against $B$. subtilis and B. licheniformis isolated from wheat bread. Journal of Applied Microbiology, 85(3), 621623. https://doi.org/10.1046/j.13652672.1998.853540.x

Skinner, K.A. and Leathers, T.D. (2004). Bacterial contaminants of fuel ethanol production. Journal of Industrial Microbiology and Biotechnology, 31(9), 401-408. https://doi.org/10.1007/s10295-004-0159-0

Salmenkallio-Marttila, M., Katina, K. and Autio, K. (2001). Effects of Bran Fermentation on Quality and Microstructure of High-Fiber Wheat Bread. Cereal Chemistry, 78(4), 429-435. https://doi.org/10.1094/ CCHEM.2001.78.4.429

Sanz Penella, J., Collar, C. and Haros, M. (2008). Effect of wheat bran and enzyme addition on dough functional performance and phytic acid levels in bread. Journal of Cereal Science, 48(3), 715-721. https://doi.org/10.1016/j.jcs.2008.03.006

Spicher, G. and Stephan, H. (1999). In Handbuch sauerteig biologie, biochemie, technologie, $5^{\text {th }} \mathrm{ed}$. Behr's Verlag, Germany: Hamburg.

Sullivan, M.L. and Bradford, B.J. (2011). Viable cell yield from active dry yeast products and effects of storage temperature and diluent on yeast cell viability. Journal of Dairy Science, 94(1), 526-531. https://doi.org/10.3168/jds.2010-3553

Torkamani, M.G., Razavi, S.H. and Gharibzahedi, S.M.T. (2015). Critical quality of Iranian taftoon breads as affected by the addition of rice bran sourdough with different lactobacilli. Quality Assurance and Safety of Crops and Foods, 7(3), 305311. https://doi.org/10.3920/QAS2013.0375

Toufeili, I., Melki, C., Shadarevian, S. and Robinson, R.K. (1999). Some nutritional and sensory properties of bulgur and whole wheat meal kishk. Food Quality and Preference, 10(1), 9-15. https://doi.org/10.3920/ QAS2013.0375

Vollmar, A. and Meuser, F. (1992). Influence of starter cultures consisting of lactic acid bacteria and yeast on the performance of a continuous sourdough fermenter. Cereal Chemistry, 69, 20-27.

Zhang, H.J., Zhang, H., Wang, L. and Guo, X.N. (2012). Preparation and functional properties of rice bran proteins from heat-stabilized defatted rice bran. Food Research International, 47(2), 359 - 363. https:// doi.org/10.1016/j.foodres.2011.08.014 